\title{
Coleridge's Colonial Interest in Abyssinian Christianity
}

\author{
Pyeaam Abbasi \\ English Department, Faculty of Foreign Languages, University of Isfahan, \\ Hezar Jerib Street, Isfahan 0311-8174674331, Iran \\ e-mail: Pyeaam77@yahoo.co.uk
Alireza Anushiravani
College of Humanities (Building No. 4), University of Shiraz, Eram Square, Shiraz, Iran.
e-mail: anushir@shirazu.ac.ir

\begin{abstract}
Coleridge's radical and colonial interests can be explored in his 1790 poems as sites of power and resistance. As a product of the complex discursive web of the $18^{\text {th }}$ century, the Orientalist Coleridge could not act out of such historical forces as colonialism that had gone into shaping him and his poetry. Although he attacked European corruption and desired a revolutionary figure such as Mahomet to make a return to Abyssinia as home to true Christianity, Coleridge perpetuated the prejudice of Christianity's superiority over Islam. Disillusioned by the French Revolution, Coleridge created Mahomet to replace Napoleon to pave the way to Abyssinia where true Christianity began. This study is an attempt to show that Coleridge's radical interpretation of Mahomet, and desire for the Abyssinian maid and a Pantisocratic setting are all ideologicallyshaped discursive practices within the context of $18^{\text {th }}$ century colonialism. With such political elements as colonization in mind, a better historicallyengaged understanding of Coleridge can be achieved.
\end{abstract}

Key words: coleridge, colonialism, religion, Mahomet, Abyssinia, christianity

Texts are carriers of ideologies, for according to Day (1996) texts are "ideological formations which are specific to particular societies at particular phases of historical development” (p. 125). Romantic poems as texts reflect such discourses as imperialism and colonialism circulating in so many of the texts that both shaped and were shaped by the British 
culture during the final decades of the $18^{\text {th }}$ century and the early decades of the $19^{\text {th}}$. Spivak (1999) believes "nineteenth-century British literature cannot be read 'without remembering that imperialism ... was a crucial part of the cultural representation of England to the English' "(as cited in Knellwolf \& Norris, 2007, p. 244). Coleridge as the product of the discursive web of the $18^{\text {th }}$ century has given birth to poems that, like any other discourses, are "sites of power and resistance" (Malpas \& Wake, 2006, p. 61) and carry traces of his radicalism as well as oriental inspirations. I do not see eye to eye with Wallace Cable Brown's words that "the Romantics were interested in Eastern matter for personal literary reasons and not for religious or political propaganda" (as cited in Oueijan, 2000, p. 5). After all Orientalism is, according to Said (1978), "a political vision of reality" (p. 43), and Coleridge's poems cannot exist independent of the socio-political realities of his time. It is noteworthy that "no production of knowledge in the human sciences can ever ignore or disclaim its author's involvement as a human subject in his own circumstances" (p. 11) which means that a work of literature is not something separable from the sociological phenomena of its time. Coleridge's poetic statements are neither fully complicit with nor resistant to the colonialist ideologies of his age but a mixture of sundry inspirations married in his unifying imagination.

Coleridge's Orient is an imaginatively created site for the fulfillment of frustrated dreams of fraternity, liberty, love and uncorrupt (Abyssinian) Christianity. Coleridge's awareness of the Orient is aesthetically and imaginatively shaped in his Religious Musings (1794), Pantisocracy (1794), The Rime of the Ancient Mariner (1798), Kubla Khan (1799) and Mahomet (1799) as instances that will be referred to. Being a product of the network of $18^{\text {th }}$ century discourses, Coleridge produced poems that reflect the interaction of the poet with the discourses of his time as well as the knowledge produced about the Orient. Greenblatt (1989) states that "the work of art is the product of a negotiation between a creator ... equipped with a complex, communally shared repertoire of conventions, and the institutions and practices of society" (p. 12). It is in his poems that Coleridge makes knowledge about the Orient the result of which would then be either aesthetic possession of or contribution to the geographical possession of the Orient. The East was a suitable context on which the West could project its fears and aspirations, and an Eastern setting like Abyssinia could provide Coleridge with a desired place to seek refuge from 
Western corruption and simultaneously project his fantastical ideas of oriental conquest. Although Coleridge seems to attack European corruption and false religion of the Christian West by desiring Mahomet to bring liberty, he perpetuates the prejudice of the binary opposition of Christianity and Islam. He believes the Abyssinian Christianity to be the true religion Christ had taught however, identifying the Abyssinian maid with Abyssinia as a pure, primitive land is an indication of Coleridge's colonial interest in the Abyssinian Christianity.

Eastern cultural, political and historical values have been ignored by many Orientalists which has resulted in subjective description and evaluation of the East: Johnson portrays the Happy Valley and beautiful gardens in his Rasselas (1759); Exotic landscapes appear in Shelley's The Revolt of Islam (1818), Beckford's Vathek (1782) and Moore's Lalla Rookh (1817); and Byron's portrait of the slave market in Don Juan (181823) is subjectively Orientalist. That is why Orientalism appears in as many forms as textual, imaginative, biblical, cultural and aesthetic other than military, political, geographical and economic. Orientalism as a Romantic poetic element has been influential in shaping Romantic poetry, thus a rejection of Jackson's (2008) belief that "the Romantic literary experiment ... emerges as a unique instantiation of the discourse of autonomy" (p. 106). The shaping power of socio-economic forces like the slave trade gave birth to so many of the contemporary texts. Accordingly, Armstrong (1987) believes that "political power rests within the literature that molds our ideology, and it is an ideology in which we all are complicit in constructing” (pp. 26-7). There is no doubt that trade was very important to the British government however, Coleridge saw it as the cause of despotism as well as "corruption of the true constitution of England," and believed that men "must abandon struggle for wealth, and ... must curb economic competition by legal regulation of hours and conditions of labor" (Brinton, 1962, p. 84). Coleridge had noticed that it was Islam that emphasized prohibition of the slave trade as a pagan one. He hated despotism and terror believed to go back to the earlier histories of Muslim armies. He was a fervent adherent of Priestly as a republican hero fighting against superstition and despotism whom he admires in Religious Musings (1795) as a "patriot, and saint, and sage" (l. 372). In his Statesman's Manual (1816) and Church and State (1830) Coleridge showed his enthusiasm for reform while showing that he was not unaware of the power relations between Church and State. The universal reform Coleridge 
desired was possible by such revolutionary figures as Mahomet but as Coleridge says in his Anima Poetae, he had to construct Mahomet either as "representative of unipersonal Theism" or as "an idolater with his gods ... and a fetish-worshipper who adored the invisible alone” (1804, p. 290). This confirms the power of socio-political representations of his day against which he desired to bring up a model so that he could critique Western corruption.

The Oriental setting of the garden in Kubla Khan has a lot to offer regarding Coleridge's radical views of reform. There is the possibility of the Persia of $13^{\text {th }}$ century's inexact, fanciful and abound-with-luxury descriptions as the model for the garden. That Persia in Mandeville's words was "an earthly paradise, the cradle of Biblical story, bounded by one of the four rivers that came out of the Garden of Eden.” Persia was "a country of luxury, light, and colour, of gardens sunlit and scented, murmurous with bird song and the sound of running water" (Heseltine, 1953, p. 361). The otherness of the garden is reflected in Coleridge's poem: there is no musicality in the poem and the stanzas are neither coherent nor regular; the poem is full of anxiety and strange names; sound effects are lush; and the sub-title A Vision in a Dream. A Fragment is anti conventional. There is "holy dread" (1. 52) in the garden suggesting beauty and terror. The poet wishes to revive the song of the Abyssinian maid from Abyssinia where he knew to be home to primitive and true Christianity as well as "the Garden of Eden, where language began” (Bloom \& Trilling, 1973, p. 256). The despotism and idolatry portrayed in Kubla Khan suggests corruption, and can be read as Coleridge's projection of Western fear and hatred of corrupt religion on the East, as well as an implied attack on the very Western priesthood, aristocracy and false religion. The motif of tyranny was not new in Coleridge: Kubla is like Shelley's Othman representing superstition and absolute power; Landor's Gebir (1798) also represents Oriental despotism; Vathek is also a tyrant however Kubla is not shown as him to be sensual and with a lust for occult power. In Kubla Khan where visionary reconciliations are displayed, the hidden cultural voices reveal Coleridge's revolutionary thoughts. To Coleridge desiring reformation Abyssinia was important for her "conversion ... from pagan idolatry to Christianity ... of the pagan temples into Christian churches" (Leask, 1998, p. 16). What was appealing to Coleridge's mind was the primitivism implied in Paganism. In the 1790s Coleridge, influenced by Southey's poetry and thoughts regarding a revolution in which liberty and equality would smash the idols 
of priest craft and tyranny, believed that conventions were types of idolatry and would try to break free from the constraints of political life determined by the corrupt Church and State. Idolatry, for Coleridge, was anything that threatened the stability of the society or the universal bond, for any institution to Coleridge was a structure of power-it is noteworthy that revolution and universal bond or leadership were the major themes in Southey's oriental poem Thalaba: The Destroyer (1801). The creation of Kubla as the idol of tyranny in an Oriental land of pure and primitive instincts and joy shows Coleridge's worries regarding corruption in his own country as well as the threat to domestic appeal. Coleridge's desire was to free mankind from political tyranny of tyrannical despots represented in the figure of Kubla. What is crucial to a revelation of hidden meanings in Kubla Khan is that Coleridge would see Africa as representative of a remote and primordial age of antiquity as he was always thinking of distant lands to set his own utopian society. McKusick states that to Coleridge "the exotic islands of the South Pacific seemed to offer a safe haven for revolutionary enthusiasm” (Fulford \& Kitson, 1998, p. 108). Coleridge, according to Woodring (1990) had produced the following words in Table Talk: "colonization is not only a manifest expedient-but an imperative duty on Great Britain. God seems to hold out his finger to us over the sea” (p. 369). On the one hand, Coleridge encourages voyages to the unknown and keeps his eye on distant lands, and on the other as in The Rime he critiques colonialism by showing the condition of the sailors abroad, and the English domesticity being threatened. To this Coleridge's colonial interest in Abyssinia must be added. The identification of the Abyssinian land as a distant one with the Abyssinian maid reminds us of McClintock's (1995) belief that "the myth of the empty land is the myth of the virgin land" (p. 364) which confirms a colonizer's colonial look at a feminine East waiting to be conquered.

One possibility for Alph suggesting beginning is that Coleridge supposed that "the Garden of Eden, where language began, was in Abyssinia, and with memories of the classical river Alpheus, which ran underground" (Bloom \& Trilling, 1973, p. 256). It originates from the Garden of Eden or a paradise that is walled off like Milton's Paradise suggesting beginning, virginity and primitiveness. Another possibility for the river is that it comes from Alph Laila Wa Laila while Leask (1998) offers “Southey's yellow, stained 'whang-ho' with its Tartarian origin” as a source (p. 9). The river as a primordial image may be a reference to 
Abyssinian Christianity that was, to Coleridge, pure and uncorrupt. The river heading for the sea suggests redemption and removal of despotism so that one may be revolutionized for embracing a pure creed in a utopian setting. The "deep romantic chasm" (1. 12) of the poem is holy, demonic, savage, wild and pure with the power to overflow, erupt, revolutionize, destroy, give birth and redeem. It is noteworthy that the image of rushing rivers appears in "Religious Musings" as well. The tendency of revolution was also shared by Southey whose Thalaba destroys the false paradise of Aloadine the oriental magician. Coleridge and Southey would think of the future leader as politically uncorrupt, a product of the innocent and peaceful nature, and seeker of truth. In Kubla Khan Coleridge projects sublime thoughts about true religion, and his hatred of false religion, inequality, corrupt Christianity and political slavery on the East, and desires a return to the Abyssinian Christianity as the true, primitive and pure Christianity that binds all together and to the Vast. Coleridge does not take primitivism to mean backward or less fully human but true and original. Southey was against "false religious ideologies in which their promises of heavenly rewards for death are meaningless wars" (Leask, 1998, p. 5). Coleridge would look at the East as home to heavenly religions. That is why he selects an oriental setting to escape Western corruption and zoom Western look on the East. Yet, the Romantic conqueror must be careful, for there are forebodings of war within: Oriental despotism.

In the first part of the poem, the radical Coleridge of the 1790s creates the Xanadu of an oriental despot exerting his cruelty upon nature. The ideas of wealth and luxury are brought to the mind of the reader who may imagine a "decadent Utopia” (Meyer, 1991, p. 667) where tyranny, inequality, State priesthood and the corrupted version of the true religion of Moses are practiced. The second part of the poem introduces Abyssinia where there is the chance of a song to be revived and primitive Christianity practiced if only the maid's song can be revived or if only the Romantic poet can conquer her. But if so then "Beware! Beware!” (1. 49), for he has been exposed to the oriental and has "drunk the milk of Paradise" (l. 54). Coleridge was always worried about racial mixture that would put the British family in danger. Coleridge's frequent use of oriental motifs is an indirect way of approaching the matter of the French Revolution and a desired utopia in a way not to be identified with conspiracy in such an age of political unrest. On the one hand Coleridge needed a model to compensate for the Revolution's loss and, on the other, he did not want to 
be identified with French Jacobins or English Unitarians as each could be reminiscent of the other. The river runs in the garden as a redeeming force to purge men of corruption and bring life to the desired utopia. Wordsworth in book 6 of his Prelude (1799) sings of "the mighty flood of Nile / Poured from his fount of Abyssinian clouds/To fertilize the whole Egyptian plain" (ll. 615-17). McGann (1981) says "before Coleridge, the Church for centuries had been the principal ideological state apparatus" (as quoted in Natarajan, 2007, p. 139), and Coleridge who was a defender of a national church believed that corrupt churches were absolutely incapable of bringing truth to people, and his view of the corrupt church was a monopolized state instituted by a Hobbesian sovereign where it was impossible to place his constitutional theories. To the radical Coleridge these had to be purged.

Dissatisfaction with the French Revolution turned Coleridge's (1978) attention towards Islam and its prophet that were systematically misrepresented and distorted images. According to Said, Islam was shown to be "a fraudulent new version of ... Christianity" (p. 59) and its prophet an imposter ruling over a people that had "no sense of discipline" and being "good rioters and bad fighters" and "if encouraged, they make an infernal nuisance of themselves" (Koestler, 1959, p. 155). Coleridge's disillusionment of the French Revolution-a theme in "France: An Ode" (1798) - made him turn to another model and shape the culture by changing already-established views. Circulation of Mahomet's distorted image was a totally discursive act of justifying dominance, difference and superiority over Islam. Coleridge had no way out of this circulation of power because it was precisely what had given birth to him. However, Coleridge as a visionary poet treated Islam and Mahomet out of the religious bounds of the English culture. Kubla Khan was written in August 1799 but was not published until 1816. The preface displays Coleridge's 1816 conservative act of disavowing the Muslim-Unitarian link, suppression of his 1790 radical ideologies, and introduction of psychology and drug as the starting point while in 1790s Coleridge was a radical exploring his political anxieties in his poems. Coleridge's implied tendency to Unitarian Islam as a compensator of what was lost in the French Revolution is conspicuous in Unitarianism of Kubla Khan as an oriental poem. Coleridge confirms ideologies of his time, yet shows resistance towards some of them which can be found in the imaginative reconciliation of opposites that is the very Coleridgean theme. Coleridge adds the flavor 
of imagination to the existing realities to shape the reality of his own mind and the Orient. As a practitioner of orientalist poetry Coleridge creates his own Orient and I do not insist on seeing Kubla's garden as a model after the so-called Assassin's garden valley. This is what Lowes and Elizabeth Schneider strongly support turning Coleridge's intent to a manifestly Orientalist one. Certainly there are similarities between different texts and each writer takes part in the circulation of knowledge however, Coleridge creates something new out of the impressions he receives. Coleridge's imagination gives birth to Mahomet that "scatter'd ... blessing" and "evil" (1. 2). Mahomet is the producer of "huge wasteful empires" (1. 3) and has "crush'd the blasphemous rites of the Pagan / and idolatrous Christians" (ll. 4-5). The word evil that appears in "Mahomet" is important, for Coleridge intended to remove the "motives of evil" like private property from his Pantisocracy (Holmes, 1998, p. 78). "Mahomet" was part of an intended, desired, Islamic, unfinished epic on which Southey and Coleridge collaborated. They intended Mahomet as an idol-breaker, a liberator, a revolutionary figure and a savior. Coleridge would portray his own understanding of Mahomet which meant that he was an observer of the Orient and tried to approach her in a British effort of knowing her. However, the figure of Mahomet is not projected as an "other" in the poem but is more of a politicized and ideological construction in an oriental setting. Coleridge's and Southey's collaborative work to which Mahomet was the short contribution was called The Flight and Return of Mohammed whose radicalism is manifest in Coleridge's Mahomet and Kubla Khan, and Southey's Thalaba.

The image of Islam appeared in The Nights as a background. Westerners had tried to show Islam as a threatening ideology and a danger to the universal bond associated with Christianity. Orientalists would attribute meekness to Christianity and fanaticism to Mohammedans. Renan (1896), the French historian, referred to the obviousness of "the actual inferiority of Mohammedan countries" (p. 85) and Europeans would project repressed desires onto the orientals lacking individuality. The West would try to appropriate the image of Islam with its "Western style for dominating, restructuring, and having authority over the Orient" (Said, 1978, p. 3). “The European encounter," Huntington (1996) believes, "with the orient ... turned Islam into the very epitome of an outsider against which the whole of European civilization ... was founded" (p. 70). However, ideals of liberty and brotherly love were sought in Islam after the 
discouraging French Revolution. Sharafuddin (1994) also states that "the Romantic movement emerged as resistance to massive despotism, and that its writers were reacting against political and cultural centralization” (p. xvii). It was the Orient that "liberat[ed] them [the Romantic poets] from the chains of Classical traditions" (Oueijan, 2000, p. 5), and Coleridge as an experimenter of liberty liberated himself, through self-observation, from stereotypically-made beliefs. Coleridge's counter-discursive attempts and dissenting voice questioned cultural stereotypes but the question remains that to what extent it is possible for a Western Romantic poet to liberate himself from political and religious ideologies of his time and compose poems based on oriental matter. Romantic poets were ambiguous in their sentiment towards Islam. "On the one hand, [Islam] offered a convenient symbol of the tyranny they all sought to overcome" while on the other, Islam "offered an alternative to the compromised or corrupted political and social systems of Europe” (Sharafuddin, 1994, p. xxi). Coleridge was under the influence of this ideology in 1780 and felt Islam to be a displacement or an alter ego for Christianity willing to shatter the universal bond. However, the politico-historical context of the $18^{\text {th }}$ century and the deconstruction of fixed binaries placed emphasis on the radicalism and Protestantism of Islam.

The influence of ideologies of Oriental danger and threat was significant on the European mind since the $8^{\text {th }}$ century. In the $18^{\text {th }}$ century it was Oriental despotism that shaped the West's view towards Islam which, of course, was a kind of projection of fear, difference, terror and aspiration on the East. The interaction of the Western Christianity and Eastern Islam is the confrontation of two world powers or two cultural histories. Hachicho (1964) believes that "English (and in fact European) interest in the Near East came with the rise and spread of Islam all over the lands" that were "associated with the Holy Scriptures, as an antagonist religion to medieval Christianity" (p. 196). And in the $19^{\text {th }}$ century, dissatisfied with the French Revolution's promises of liberty and fraternity, Coleridge and many others changed view of Islam: it was the only way of salvation! Coleridge's Mahomet in which the Christian perspective is maintained can be read as an example of a subversive voice that survived the powerful cultural forces that might have silenced its message of Islam as survival not threat. The attempts of Western orientalists to show Islam as an aberration and a threat to Christianity served Coleridge to be attracted towards the 
Eastern Islam despite the fear of invasion from the Islamic East that had been implanted in his mind.

Coleridge's ambivalent look towards the East is explored in his poem that is written within the contexts of war, revolution and political struggles as main forces in the network of the $19^{\text {th }}$ century British culture. Coleridge had relied on the French Revolution to bring improvement of mankind as well as better political conditions. Disillusioned with the event, Coleridge conducted a revolution in his mind and thought of Islam as a good model for his revolutionary ideas. It must be mentioned that to the radical orientalist Coleridge, Islam itself was not the goal but the means that could pave the way to Coleridge's libertarian, simple, Pantisocratic and true Christianity. The Orient had always been a proper reservoir of inspirations for Coleridge to practice his unique Western and revolutionary themes. It is said of William Jones that "fervently called on Western authors to imitate Oriental literatures in order to renovate their own national heritage" (Ferber, 2005, p. 483). Beckford's Vathek and The 1001 Nights were influential in shaping Coleridge's political ideas who was already influenced by Southey's thoughts, poetry and his project on a world revolution. According to Sharafuddin (1994), Southey's view towards Islam, implicit in his Thalaba, was "more than positive, but he deliberately avoided explicit commendation" (p. 131) which shows the power of discursive formations on the Western consciousness and Coleridge's ambiguous look at the East.

Coleridge both incorporates and challenges major ideologies of his day. He believed that "Western Christendom and particularly Protestant culture has absorbed Christian ideas, however imperfectly, into its actual structures” (Hedley, 2003, p. 292). In an act of radicalism Coleridge, in his Mahomet, tried to change the distorted image of Islam and show resistance to the false orientalism of his day. Radicalism was a political force (and discourse) during the 1790s and Coleridge's radical interpretation of contemporary events showed itself in the belief that "the fall of kings and the violence of revolutions will be balanced and reconciled on the scales of divine justice" (Brice, 2007, p. 126). The ontological creation of an Orient in Kubla Khan or Mahomet is more in line with Coleridge's political interests and fantasies rather than being an emphasis on difference. Coleridge as a radical was engaged with Islam, and Mahomet was Coleridge's radical idealism inspired by it. Coleridge's imaginative vision would see Islam as a revolutionary culture, an alternative of earlier 
Protestantism, and anti-Trinitarianism or "Socinianism” that Hedley (2003) would call "one marginal product of Reformation theology" and a "strong rejection of the doctrine of the Trinity" (p. 50). Coleridge's message in Mahomet could face overwhelming opposition by the British government had he not conservatively married opposing images in his esemplastic imagination. 1794 marked Coleridge's immersion in Unitarian theology and multifarious reading of Joseph Priestly, the well-known Unitarian philosopher of the time, who was himself under the influence of Thomas Emlyn the Unitarian Minister. Coleridge came to be fascinated with the Unitarian Islam as a fictional narrative. He could not be explicit with his Unitarian beliefs, for Unitarianism was associated with conspiracy, French Jacobinism, and Church adversaries. The reason for Coleridge's attraction to Unitarianism was his hostility towards Trinitarian Christianity. Brown (1982) sees Islam representing "a return to the original Mosaic theocratic or theopolitical idea” (p. 372). Accordingly Mahomet can be viewed as the return of the repressed in a dissenting, unorthodox writer with the body of his Unitarianism disguised in the cloak of conservatism, for conservatives were known as possible conspirators or dissenters who were against the establishment. In Mahomet Coleridge has followed the ideology of Christian rightness and Pagan wrongness and sees otherness in Paganism, and self in Christianity, and conservatively makes Islam the Ideal-Self.

Byron, in Don Juan, celebrates the Nile and supports Napoleon while showing disgust for Muslims and Islamic rituals. Southey in his Indian poem The Curse of Kehama refers to the Muhammedan religion the information for which he brought from The Nights! A prominent work of art read by Coleridge was Voltaire's Mahomet the [i]mposter in which the writer's skepticism, satire and anti-Islam tendencies are shown in the portrayal of Mahomet. Voltaire believed that superstition was at the heart of every religion, and Edward Gibbon, the $18^{\text {th }}$ century writer with whose works Coleridge was familiar, believed in prophets as men who were flawed and could make mistakes. It was believed that "wherever there has been murder, war, protracted conflict involving social horrors, Islam clearly played an important part” (Said, 1981, p. 79). There is no doubt that Coleridge changed the view of Islam with his words; however, it should not be ignored that by the turn of the $19^{\text {th }}$ century the shift in Coleridge's sentiment towards Islam was a conservative act of hiding his radical ideas and justification of his colonial interests. Coleridge seemed to question the earlier ideology of the superiority of Christianity over Islam but was sure of 
it as the only means of a second coming if such a thing was expected. He had shattered, indirectly, that full-of-horror image of Islam and, in line with S. Johnson, E. Burke, and P. B. Shelley, believed in the reactionary Islam as a political discourse that could raise and support what was low in England. Islam had emphasized egalitarian values and liberty, and this could not be left unnoticed to a radical, dissenting, and Unitarian poet in favour of the Protestantism of Islam. But the operation of ideologies through contemporary texts was so strong that Coleridge felt he had the right to change his material in order to suit his and his audience's Western appetite. Coleridge seems to reconcile Christian and Islamic inspirations but what is seen is more an appropriation of Eastern material rather than a politically neutral reflection. It is Western reconstruction of the Middle East Culture that was always a source of imagination to Coleridge.

Nevertheless, 1790s marked Coleridge's interest in the figure of Mahomet as a Promethean figure or a liberator on whom was projected the features of a Romantic hero. Mahomet became the Napoleonic figure who would restore what was lost in the course of the French Revolution. The word Mahomet did not mean superstition or despotism any more but the end to superstition and Church / State corruption, and Mahomet was to restore Christ's "truth," "love," and "Equality." Stubbe (1975) says Mahomet's mission was to "restore the old religion, not to introduce a new one. He taught his followers ... that 'there was one God' with no Associates” (p. 180). Coleridge (1971) in his poem Mahomet defended Mahomet the "enthusiast" who would defeat "idolatrous Christians" (1. 5) of the West. Coleridge's Mahomet was a revolutionary figure that would use the discourse of religion to push forward his cause and was associated with revolution, passion, enthusiasm, energy and power needed to reform both the world without and the world within. Since his youth being a Jacobin and sharing revolutionary zeal with Wordsworth and Southey, Coleridge believed in the necessity of reform.

Mahomet overthrows idolatrous beliefs and priesthood tyranny, and heralds a peaceful, uncorrupted setting devoid of despotism. Most important to Coleridge was moral revolution: by the revolutions he expected to occur in Britain, he hoped for a more perfect and equal society. He desired to find an oriental figure and setting as the utopia proper to lost visions and Pantisocracy programs. Under the influence of David Hartley's Observations on Man, Coleridge paid more attention to the relationship between nature and a moral world. Writing on the Orient was a kind of 
return of the repressed viable through the power of the imagination. Under the influence of discursive formations and worried about Britain's corruption, Coleridge would encourage the return to primitivism and equality as the foundations of true Christianity. From a Rousseauist's point of view, Coleridge was an adherent of nature, for "there can be no disagreements over personal property, since property does not exist in the state of nature" and slavery will not have a place either "since no man can bind another to his will” (Mckusick, 2005, p. 415). Burning with millennial expectations, Coleridge was attracted to nature more than ever and would think of his Pantisocracy the idea of which can be better understood if put next to Kubla Khan and Mahomet.

The word Pantisocracy or an all-equal-society coined by Coleridge and also a poem by him meant "a utopian community in which power and produce would be shared equally amongst all its members" (O'Flinn, 1988, p. 75), for Coleridge believed if all reasoned they were equal. Lee (1998) says Pantisocracy was "a government of self-rule that emphasized the equality of all its members" (p. 694) as well as the peace brought by its government. It is noteworthy that Coleridge knew Africa as an "innocent and happy" world where peace dominates (Coleridge, 1971, p. 240). The qualities of joy and peace can be reminiscent of the setting in which the Abyssinian maid sings. The Pantisocratic Coleridge never emphasized Africa's savagery or backwardness as was the case with many other writers, and was after a mixture of or reconciled version of Arab and Christian pastoralism both in nature and imagination, for the ideal to him was a reconciliation of opposing values. Again the influence of a contemporary poet cannot be ignored: Southey's Thalaba as a "Bedovin herdsman ... descends as an iconoclast on Baghdad and other corrupt cities of the plain, imposing by force their return to an ideal republican simplicity" (Butler, 1990, p. 143). The Neoplatonic belief that "all created things were ... evolving towards their divine source" (Wylie, 1984, p. 497), and the need for liberty were dominant in the last decades of the $18^{\text {th }}$ century. Writing on "liberty," Coleridge would try "to reconcile the universal and pure idea of liberty with the quotidian need for stable, efficient, and practicable government in the moral world" (Edwards, 2004, p. 33). In Destruction of the Bastille (1789) Coleridge sings "Yes! Liberty the soul of life shall reign, / Shall throb in every pulse, shall flow thro' every vein!” (ll. 49-50). McKusick (2005) believes that Bastille was "a symbol of tyranny" and it "stood for all that was corrupt, depraved, and 
unnatural in contemporary French society” (p. 416). If distant lands could be conquered, Coleridge would revive the Abyssinian song and practice his ideals! That is when he will "see the rising sun" and feel "new rays of pleasance trembling to the heart” (Coleridge, 1971, Pantisocracy, ll. 13-4).

In his lectures Coleridge would emphasize equality of conditions, and he wanted to establish his utopia on social equality. He won a prize for a Greek Sapphic ode on the iniquity of the slave trade. He believed that in a state that slavery is practiced "the rulers form and supply the opinions of the people" while "a people are free in proportion as they form their own opinions." He believed that "in the strictest sense of the word Knowledge is Power" (Appleyard, 1965, p. 16). This revolutionary vision is celebrated in Coleridge's Pantisocracy as a description of a utopian dream. The relation between the French Revolution and Pantisocracy was obvious in the radical spirit of the age. For him the Revolution was a struggle for individual liberty and freedom of mankind that are the essential features of true religion. Coleridge's To a Young Ass that was composed with Pantisocracy also mentions his idea of Pantisocracy or government by all. The poet wishes to take the brother-ass "to the Dell, / Where high-soul'd PANTISOCRACY shall dwell!” (1l. 27-8). Coleridge was against any kind of idolatry and was worried about perversion of ideals. He names "priests idolatrous" (Religious Musings, l. 374), and idolaters of one's self that ignore fraternity: "For She hath fallen/On whose black front was written;/ She that reel'd heavily, whose wine was blood;/She that worked whoredom with the DAEMON POWER, /And from the dark embrace all evil things / Brought forth and nurtured ....” (ll. 342-7).

In Religious Musings the circumstances of life in the 1790s gave birth to Coleridge's ideas, and the dream made on the socio-political conditions fueled his imagination. According to Cain (2003), Pantisocracy is an "experimental and ideal community founded on human reason and directed toward human perfection" with emphasis placed on "land in common," "brotherhood of mankind,” and "nature” (p. 298). However, in Frost at Midnight (1798) Coleridge hopes his son, Hartley, to become a colonizer of nature - perhaps America where he knew as a pure and simple land uncorrupted by British civilization-which shows that his interest in nature or the East is not anti colonialist. Bowra (1969) believes that Romantic poets fuse "imagination and truth," for "their creations are inspired and controlled by a peculiar insight" (p. 7) and that insight is the web of orientalist and colonialist discourses. Said (1978) defines 
Orientalism as "the discipline by which the Orient was (and is) approached systematically, as a topic of learning, discovery and practice” (p. 73). Coleridge approaches the Orient in his poems, and the Orientalism practiced by Coleridge is textual. Coleridge and his poems are culturally constructed and are, therefore, open to oriental inspirations. Coleridge's poems as carriers of colonialist ideologies are not neutral reflections of the reality of the Orient or true narratives of certain unchanging events. Coleridge's references to Mahomet or Abyssinia as Eastern cultural motifs might be interpreted as his resisting voice but they are more indicative of his colonial and orientalist interest in the East which is the result of the surrounding historical forces. This is why he prefers to be symbolic in his poems. The reason Coleridge prefers symbol over allegory is that the latter "is used by radical groups" and "encourages precisely that sort of abstract thought that appeals to mobs and then produces tyranny" (Fried, 2006, p. 772). The new object of Coleridge's visionary soul is the Christian religion practiced in an uncorrupt Oriental setting and restored by an Islamic Romantic figure all of which find reconciliation in his volatile imagination and fulfill his colonial wishes.

\section{REFERENCES}

Appleyard, J. A. (1965). Coleridge's philosophy of literature: The development of a concept of poetry. Cambridge: Harvard University Press.

Armstrong, N. (1987). Desire and domestic fiction: A political history of the novel. New York: Oxford University Press.

Bloom, H., \& Trilling, L. (Eds.). (1973). Romantic poetry and prose. New York: Oxford University Press.

Bowra, C. M. (1969). The romantic imagination. Oxford: Oxford University Press.

Brice, B. (2007). Coleridge and scepticism. Oxford: Oxford University Press.

Brinton, C. (1962). English political thought in the $19^{\text {th }}$ century. Harvard: Harvard University Press.

Brown, N. O. (1982). The prophetic tradition. Studies in Romanticism, 21(3), 36772.

Butler, M. (1990). Plotting the revolution: The political narratives of romantic poetry and criticism. In K. Johnson et al. (Eds.), Romantic revolutions: Criticism and theory (pp. 133-157). Bloomington and Indianpolis: Indiana University Press. 
Cain, J. (2003). An experiment in honesty: Samuel Taylor Coleridge’s The Friend. Modern Age, 45(4), 295-304.

Coleridge, S. T. (1971). Lectures on revealed religion, its corruptions and political views. In L. Patton, \& P. Mann (Eds.), The collected works of Samuel Taylor Coleridge: Lectures 1795 on politics and religion (pp. 230-256). Princeton: Princeton University Press.

Coleridge, E. H. (Ed.). (1804). Anima Poetae. London: William Heinmann.

Danby, J. F. (1975). William Wordsworth: The prelude and other poems. Southampton: Edward Arnold.

Day, A. (1996). Romanticism. London and New York: Routledge.

Edwards, P. (2004). The statesman's science: History, nature, and law in the political thought of Samuel Taylor Coleridge. New York: Columbia University Press.

Ferber, M. (Ed.). (2005). A Companion to European Romanticism. Conwall: Blackwell Publishing

Fried, D. (2006). The politics of the Coleridgean symbol. Studies in English Literature, 46(4), 763-779.

Fulford, T., \& Kitson, P. J. (Eds.). (1998). Romanticism and colonialism: Writing and empire, 1780-1830. Cambridge: Cambridge University Press.

Greenblatt, S. (1989). Towards a poetics of culture. In H. A. Veeser (Ed.), The new historicism (pp. 1-14). New York: Routledge.

Hachicho, M. A. (1964). English travel books about the Arab near East in the eighteenth century. Die Welt des Islams: New Ser, 9(114), 1-206.

Hedley, D. (2003). Coleridge, philosophy and religion: Aids to reflection and the mirror of the spirit. Cambridge: Cambridge University Press.

Heseltine, J. E. (1953). The Royame of Perse. In A. J. Arberry (Ed.), The legacy of Persia (pp. 359-382). Oxford: Clarendon Press.

Holmes, R. (1998). Coleridge: Darker reflections, 1804-1834. New York: Pantheon Books.

Huntington, S. (1996). The clash of civilizations and the remaking of the world order. New York: Simon and Schuster.

Jackson, N. (2008). Science and sensation in romantic poetry. Cambridge: Cambridge University Press.

Knellwolf, C., \& Norris, C. (Eds.). (2007). The Cambridge history of literary criticism (Vol. 9). Cambridge: Cambridge University Press. 
Koestler, A. (1959). Thieves in the night. (D. Hardy, Trans.). Landsborough Publications.

Leask, N. (1998). Kubla Khan and orientalismm: The road to Xanadu revisited. Romanticism, 4(1), 1-21.

Lee, D. (1998). Yellow fever and the slave trade: Coleridge's The rime of the ancient mariner. ELH, 65(3), 675-800.

Lowes, J. L. (1930). The road to Xanadu: A study in the ways of the imagination. Boston and New York: Houghton.

Malpas, S., \& Wake, P. (Eds.). (2006). The Routledge companion to critical theory. London and New York: Routledge.

McClintock, A. (1995). Imperial leather: Race, gender and sexuality in the colonial contest. New York: Routledge.

Mckusick, J. C. (2005). Nature. In M. Ferber (Ed.), A companion to European romanticism (pp. 413-432). Cornwall: Blackwell Publishing.

Meyer, E. (1991). I know thee not, I loath thy race: Romantic orientalism in the eye of the other. English Literary History, 58(1), 130-144.

Natarajan, U. (Ed.). (2007). The romantic poets: A guide to criticism. Blackwell: Blackwell Publishing.

Oueijan, N. B. (2000). Orientalism: The romantics’ added dimension; or, Edward Said refuted. EESE: Norte Dame University 3(1), 1-4.

Patton, L., \& Mann, P. (Eds.). (1971). The collected works of Samuel Taylor Coleridge: Poetical works (Vol. 1). Princeton: Princeton University Press.

Renan, E. (1896). Poetry of the Celtic races and other studies. (W. G. Hutchinson, Trans.). London: Walter Scott.

Said, E. W. (1978). Orientalism. London: Penguin Books.

Said, E. W. (1981). Covering Islam. New York: Pantheon Books.

Schneider, E. (1953). Coleridge, opium and Kubla Khan. Chicago: University of Chicago Press.

Sharafuddin, M. (1994). Islam and romantic orientalism. London: I. B. Tauris.

Stubbe, H. (1975). The rise and progress of Mahometanism. Lahore: Orientalia.

Woodring, C. (Ed.). (1990). Table talk. London \& Princeton: Princeton University Press.

Wylie, I. M. (1984). How the natural philosophers defeated the whore of Babylon in the thought of S. T. Coleridge, 1795-1796. Review of English Studies. 34(140), 494-507. 